\title{
貯蔵中における温州ミカン果汁の品質に及ぼす 各種容器の影響についで
}

\author{
吉田企世子* -太田英明 ${ }^{* *}$ ・百留公明*** \\ 青柳 英夫***. 岡部光雄 ${ }^{* * *}$. 薄田 亘***
}

\section{Effect of Various Types of Container on Quality of Satsuma Mandarin Juice during Storage}

\author{
(Effect of Package on Quality of Fruit Juice Part II)
}

\author{
Kiyoko Yoshida*, Hideaki Ohta**, Kimiaki HyaKudome*** \\ Hideo AoYAGI***, Mitsuo OKABE*** and Wataru SusukIDA*** \\ * Kagawa Nutrition College, 3-24-3 Komagome, Toshima-ku, Tokyo, 170 \\ ** Agricultural Technical Center, National Federation of Agricultural Co-operative Associations, \\ 5-5-1 Higashiyawata, Hiratsuka-shi, Kanagawa, 254 \\ *** Packaging Research Institute, Dai Nippon Printing Co. Ltd., \\ 591-10 Kamihirose, Sayama-shi, Saitama, 350-13
}

The influence of various containers on preservation of Satsuma mandarin (Citrus unshiu Marc.) juice during storage was examined. The reconstituted juice $\left(12^{\circ}\right.$ Brix) were hot-packed into the different containers, such as glass bottle, metal can (tin free steel) and plastic vessels etc., sealed and then cooled with water. The final juice products were stored at $37^{\circ} \mathrm{C}, 20^{\circ} \mathrm{C}$ and $/$ or $5^{\circ} \mathrm{C}$ during 3 months, and examined at regular intervals for the changes of ascorbic acid, browning (OD $430 \mathrm{~nm}$ ), hydroxymethyl furfural and sensory evaluation. The maintenance of juice quality in the standing pouch (oriented nylon/aluminium foil/polyethylene) and the paper cup laminated with aluminium foil/ polyethylene were the same as that in the glass bottle or the metal can. Whereas, the two standing pouchs (viniridene oriented nylon/polyethylene and oriented nylon/polyethylene), which were permeable to oxygen, gave the lower ascorbic acid retention, the higher browning and bad sensory score. When using $250 \mathrm{ml}$ portions of juice, the aluminium foil/polyethylene bag in box without headspace, so-called ekitight container, kept the quality of juice more than the glass bottle which headspace volume was increased each time the juices were consumed. From these results, the distribution, use and handling of the plastic containers tested were discussed. (Received Feb. 17, 1983)

近年, 果実飲料の包装容器は従来のガラスびんおよび 金属缶から内面紙にポリェチレン，ポリスチレンなどを 用いたプラスチック容器あるいは紙容器へと多様化して いる。これに伴い，各容器別による果実飲料等の内容物 のシェルフライフは市場用途との関連で重大な関心事と
なっている。これまで, 温州ミカン果汁あるいはバレン シアオレンジ果汁などのカンキッ系果汁に対しては, 主 にガラスびえあるいは金属缶を主体として貯蔵中におけ る品質変化が調査されてきた。

著者らは前報 ${ }^{1)}$ に扮いて, 殺菌条件, 貯蔵条件が洫州

†包装が果実飲料の品質に及ぼす影響（第 2 報）（前報，交献 1)

*女子栄善大学 (T 170 東京都豊島区駒込 3-24-3)

**全国農業協同組合連合会 農業技術センター（广 254 平塚市東八幡 5-5-1）

****大日本印刷 (株) 包装研究所 (T 350-13 狭山市上厇瀬 591-10) 
ミカン果汁の品質に及ほす影響について 検討し，加熱 (殺菌) 温度および加熱時間よりもへッドスペース量あ るいは貯蔵温度の影響の方が大であることを認めた。

本報では，従来のびん詰と併せて今後さらに飲料用容 器として 用途の拡大が 予想される 7 種類の容器を用い て，貯蔵中における温州ミカン果汁の品質に及ほす影響 它検討したので，その結果を報告する。

\section{実験材料および方法}

\section{1. 材料}

(1) 試料

和歌山県経姵連桃山食品工場で製造された $50^{\circ} \mathrm{Brix}$ 濃雀温州ミカン (Citrus unshiu Marc.) 果汁の凍結品を 解凍し，蒸留水で $12^{\circ}$ Brix に希釈，還元した果汁を実験 に供した。

\section{(2) 容器}

本実験で使用した包装容器を Table 1 に示した。すな わち，PET ボトル，スタンディングパウチ（スタンドパ ウチ） 3 種類，フルミニウム（Al）入り積層屋根型カー トン (L アルミ)，Al 入り積層紙カップ (HF) およびプ ラスチック部分補強 $\mathrm{Al}$ 積層カップ (ピラードパック), 金属缶 (TFS 缶)，ガラスびん 2 種類 ( $250 \mathrm{ml}$ 容と 1.8 $l$ 容)ならびにェキタイト容器 $(1.8 l)$ を使用した。
2. 万法

（1）殺菌条件拉よび貯蔵条件

濃縮僈元果汁 $\left(12^{\circ} \mathrm{Brix}\right)$ を二重金にて $93^{\circ} \mathrm{C}$ に加熱し， 各容器に熱間充嚗・密封後, 室温まで水冷した。各容器 のヘッドスペース量は市販品のそれと一致させた（Table 1)。果汁を充填した容器は $37^{\circ} \mathrm{C}, 20^{\circ} \mathrm{C}$ あるいは $5^{\circ} \mathrm{C}$ で 3 カ月間貯蔵し，経時的な 品質変化を調查した。ま た，開封後に小出しして使用する試験(ヘッドスペース の有無)には, $1.8 l$ 容ガラスびんならびにへッドスペー スが生じないよう工夫された $1.8 l$ 容エキタイト容器 (アルミニウムホイル袋) を用いて，37 ${ }^{\circ} \mathrm{C}, 20^{\circ} \mathrm{C}$ あるい は $5^{\circ} \mathrm{C}$ で 1 力月間貯蔵し, 定期的に $250 \mathrm{ml}$ ずつ小出し しながらその内容物を分析した。

(2) 酸素透過度の測定

各容器の酸素透過度は Modern Control 社製の $\mathrm{Ox}$ $\operatorname{tran} 100\left(\mathrm{ml} /\right.$ 容器・日)を用い, $20^{\circ} \mathrm{C}$, 相対湿度 $100 \%$ の条件下で測定した。

(3) 分析項目

前報1 に準拠し，フスコルビン酸，褐変度，ヒドロキ シメチルフルフラール (HMF) ならびに色調について 試験した。また，パネル 15 名により 7 段階喈好尺度法 (0土3) の官能検査を行った。

Table 1 The containers used in this experiment

\begin{tabular}{|c|c|c|c|c|}
\hline Container & $\begin{array}{l}\text { Abbreviation } \\
\text { in text }\end{array}$ & $\begin{array}{l}\text { Filling } \\
\text { volume } \\
(\mathrm{m} l)\end{array}$ & $\begin{array}{l}\text { Headspace } \\
\text { volume } \\
(\mathrm{m} l)\end{array}$ & $\begin{array}{l}\text { Oxygen permeability } \\
(\mathrm{m} l / \text { container } \cdot \text { day })\end{array}$ \\
\hline Metal can (TFS) & Metal can & 180 & 4 & 0 \\
\hline Glass bottle & Glass bottle & 250 & 5 & 0 \\
\hline Polyethylene terephtalate bottle & PET bottle & 180 & 5 & 0.5 \\
\hline \multicolumn{5}{|l|}{ Standing pouch } \\
\hline $\begin{array}{l}\text { 1. oriented nylon/aluminium foil/ } \\
\text { polyethylene }\end{array}$ & Standpack (Al) & 200 & 0 & 0 \\
\hline 2. viniridene oriented nylon/polyethylene & Standpack (KON) & 200 & 0 & 0.2 \\
\hline 3. oriented nylon/polyethylene & Standpack $(\mathrm{ON})$ & 200 & 0 & 2.0 \\
\hline $\begin{array}{l}\text { Gable top carton laminated with aluminium } \\
\text { foil/polyethylene }\end{array}$ & $\mathrm{L}$ alumi & 500 & 10 & 0 \\
\hline $\begin{array}{l}\text { Paper cup laminated with aluminium foil/ } \\
\text { polyethylene }\end{array}$ & HF cup & 180 & 1 & 0 \\
\hline $\begin{array}{l}\text { Paper cap used partially plastic and lami- } \\
\text { nated with aluminium foil/polyethylene }\end{array}$ & Pillard pack & 180 & 5 & 0.2 \\
\hline Glass bottle & Glass bottle & 1800 & - & 0 \\
\hline Aluminium foil/polyethylene bag in box & Ekitight & 1800 & 0 & 0 \\
\hline
\end{tabular}




\section{実 験 結 果}

\section{1. 容器の酸素透過度}

供試容器の酸素透過度を測定した結果を Table 1 に併 記した。

酸素の透過が 観察されたプラスチック容器は, PET ボトル, スタンドパック(KON), スタンドパック(ON) およびピラードパックの4 種類であった。酸素透過量は スタンドパック (ON) が $0.5 \mathrm{ml} /$ 容器・日と最む大き く, 次いで, PET ボトル，スタンドパック (KON) お よびピラードパックの順であった。ピラードパックを除 き残り 3 容器にはアルミニウムホイルが入っていない。

\section{2. 容器別による温州ミカン果汁の品質変化 \\ (1) フスコルビン酸の変化}

供試容器 9 種類に充填した温州ミカン果汁の $37^{\circ} \mathrm{C} お$ よび $20^{\circ} \mathrm{C}$ 貯蔵区におけるアスコルビン酸の减少を Fig. 1 および Fig. 2 に示した。

Fig. 1 および Fig. 2 の比較から明らかなように, フ スコルビン酸の残存率は貯蔵温度に著しく影箩された。 $37^{\circ} \mathrm{C}$ および $20^{\circ} \mathrm{C}$ の両貯蔵区ともアスコルビン酸の残存 率が高い方から，金属缶，ガラスびん，スタンドパック (Al), HF カップ, L フルミ, PET ボトル, ピラード パック，スタンドパック（KON）およびスタンドパック

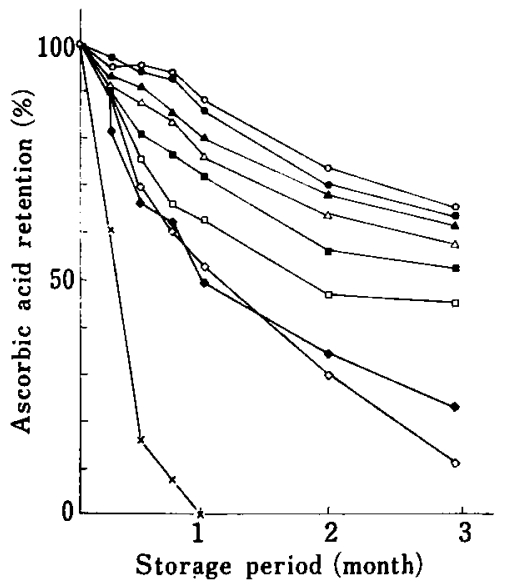

Fig. 1 Ascorbic acid retention of Satsuma mandarin juice in various containers during storage at $37^{\circ} \mathrm{C}$

Metal can -O-, Glass bottle - - , Standpack (Al) - - Standpack (KON) $-\diamond$, Standpack (ON) $-\times-$, HF cup $-\Delta-, \quad$ L alumi -n-, PET bottle - $-\square-$, Pillard pack
(ON) の順であった。このうち，スタンドパック(Al), 金属出およびガラスびんは $37^{\circ} \mathrm{C}, 3$ 力月間貯蔵でも $60 \%$ 以上のアスコルビン酸它残存していた。これに匹敵する 容器として HF カップがあった。これに対して，ピラー ドパック，スタンドパック（KON）およびスタンドパッ ク (ON) 容器中のフスコルビン酸は直線的に減少した。 特に，スタンドパック(ON) は $37^{\circ} \mathrm{C} 1$ カ月間の貯藏で フスコルビン酸はほぼ完全に消失していた。フスュルビ ン酸の減少速度が最も大きいスタンドパック（ON）で

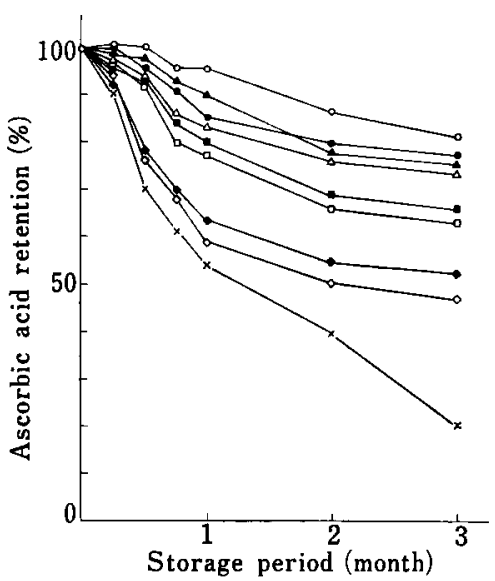

Fig. 2 Ascorbic acid retention of Satsuma mandarin juice in various containers during storage at $20^{\circ} \mathrm{C}$

Metal can -O-, Glass bottle - -.., Standpack (Al) $-\wedge-$, Standpack (KON) $-\diamond-$, Standpack (ON) $-\times-$, HF cup $-\Delta-, \quad$ L alumi - -, PET bottle $-\square-$, Pillard pack $-\rightarrow$.

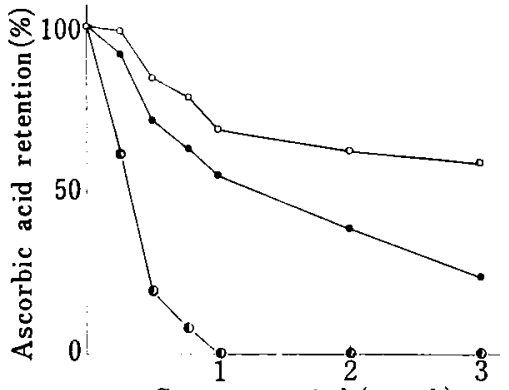

Storage period (month)

Fig. 3 Ascorbic acid retention of Satsuma mandarin juice in standpack (ON) during storage at different temperatures

$5^{\circ} \mathrm{C}-\mathrm{O}-, 20^{\circ} \mathrm{C}-, 37^{\circ} \mathrm{C}-\mathrm{D}-$. 
貯蔵温度 $\left(5^{\circ} \mathrm{C}, 20^{\circ} \mathrm{C}\right.$ およひ $\left.37^{\circ} \mathrm{C}\right)$ の影響を調查し，そ の結果を Fig. 3 に示した。

Fig. 3 から明膡なように，5ㄷ の低温眝蔵下における スタンドパック（ON）容器中のアスコルビン酸残存率 は 1 力月間䝪蔵後から減少速度が低下し，ほほ一定とな った。貯蔵開始 1 週間後におけるアスコルビン酸残存率 は $5{ }^{\circ} \mathrm{C}$ で $98 \%, 20^{\circ} \mathrm{C}$ で $93 \%$ 扰び $37^{\circ} \mathrm{C} て ゙ 62 \%$ で あった。

\section{(2) 褐变度の变化}

$37^{\circ} \mathrm{C}$ および $20^{\circ} \mathrm{C}$ 貯蔵区で検查した褐变度の増加を Fig. 4 および Fig. 5 に記載した。

褐变度の增加は $20^{\circ} \mathrm{C}$ に比較して $37^{\circ} \mathrm{C} て ゙$ 著しい。37 'C 1 , 1 カ月貯藏区でスタンドパック（ON）は直線的に 増大し，その褐变度は貯蔵開始時の約 $240 \%$ にも達し， さらにその後も潮增した。次いで，褐変度の増加が大き いものはスタンドパック(KON), ピラードパック，PET ボトルであった。これ机対して, 褐变度の增大が比較的 小さいものはスタンドパック(Al)，L アルミおよびガ ラスびんなどであった。

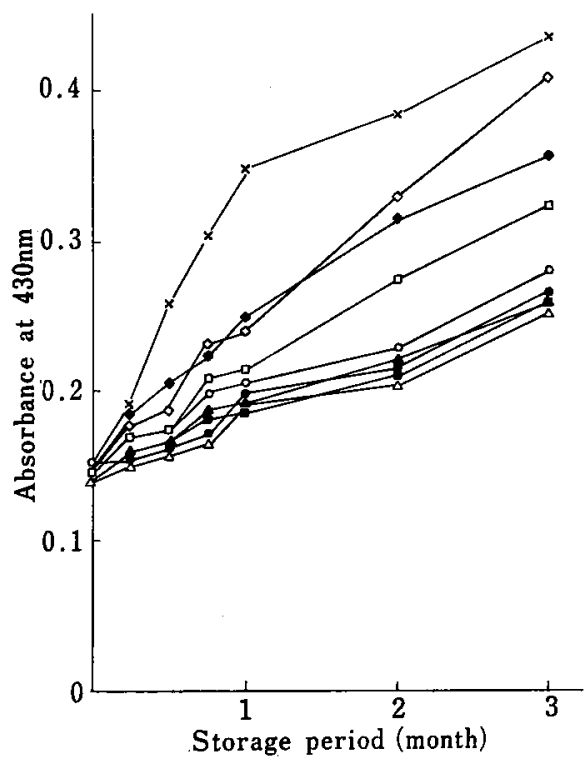

Fig. 4 Browning (OD $430 \mathrm{~nm}$ ) change of Satsuma mandarin juice in various containers during storage at $37^{\circ} \mathrm{C}$

Metal can -O-, Glass bottle - - - Standpack (Al) - - , Standpack (KON) $-\diamond-$, Standpack (ON) $-x-$, HF cup $-\triangle-$, L alumi - - , PET bottle $-\square-$, Pillard pack $\underset{-\rightarrow}{\operatorname{alumi}}$

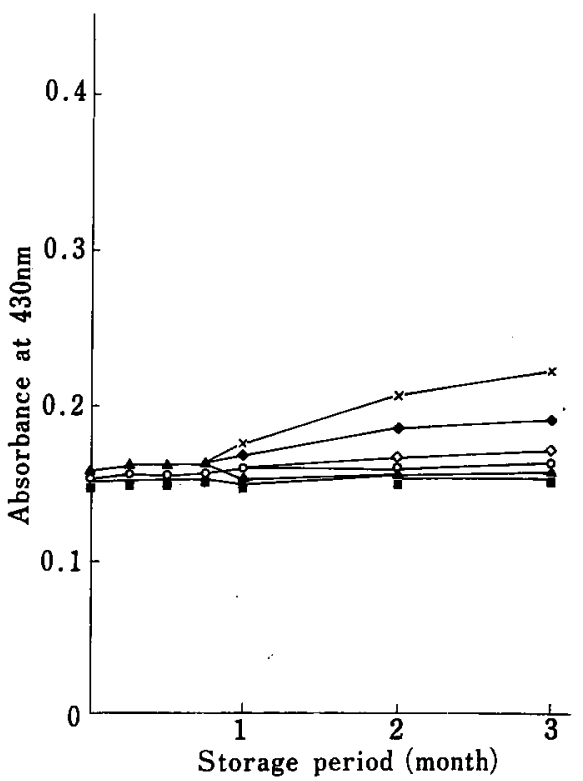

Fig. 5 Browning (OD $430 \mathrm{~nm}$ ) change of Satsuma mandarin juice in various containers during storage at $20^{\circ} \mathrm{C}$

Metal can -O-, Glass bottle - - - Standpack (Al) - - , Standpack $(\mathrm{KON})-\diamond-$, Standpack (ON) $-\times-$, HF cup $-\Delta-$, L alumi -n-, PET bottle - - , Pillard pack

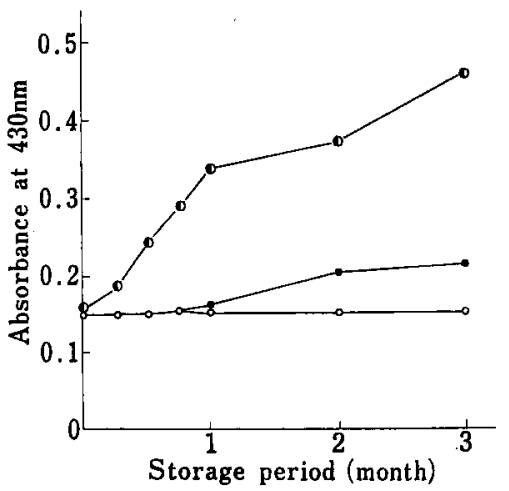

Fig. 6 Browning (OD $430 \mathrm{~nm}$ ) change of Satsuma mandarin juice in standpack (ON) during storage at different temperatures $5^{\circ} \mathrm{C}-\mathrm{O}-, 20^{\circ} \mathrm{C}-137^{\circ} \mathrm{C}-\mathrm{D}-$ 
$20^{\circ} \mathrm{C}$ 貯蔵区では，ほとえどの容器で際立った褐変度

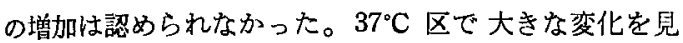
せたスタンドパック（ON）およびピラードパックは 1 カ月を経過してその褐変度が漸增し始めた。この褐変度 の增加が顕著なスタンドパック（ON）果计の貯蔵温度 による影響を調查し，その結果を Fig. 6 に示した。

Fig. 6 において，スタンドパック（ON）の褐变度は $37^{\circ} \mathrm{C}$ 区の貯蔵初期で 著しい増加が認められた。20 $\mathrm{C}$ 区 でも 1 カ月目から増加するが，5C 区における褐変度の 変化はほとえど認められなかった。3力月貯蔵後で, $5^{\circ} \mathrm{C}$ の褐变度を $100 \%$ とすると, $20^{\circ} \mathrm{C}$ で $140 \%, 37^{\circ} \mathrm{C}$ では 306\%にる及んでいた。

\section{(3) $\mathrm{HMF}$ の変化}

スタンドパック 3 種類 (Al, KON おょび ON)を用 いて $37^{\circ} \mathrm{C}$ おび $20^{\circ} \mathrm{C}$ 貯蔵区で $\mathrm{HMF}$ 量の増加を調査 しそその結果を Fig. 7 に要約した。

$20^{\circ} \mathrm{C}$ 区では, スタンドパック 3 種 ( $\mathrm{Al}, \mathrm{KON}$ おび ON) とも HMF は漸増するが, 容器間でさほど大きな 差が認められなかった。 $37^{\circ} \mathrm{C}$ 区ではスタンドパック (ON) 果汁の HMF 生成が顕著であり, 貯藏 2 カ月以降 で頡打ち状態になるものの貯蔵 3 カ月後では当初の 375 \%まで増大していた。次いでスタンドパック (KON) であり, 最も HMF 生成が少ないものはスタンドパック

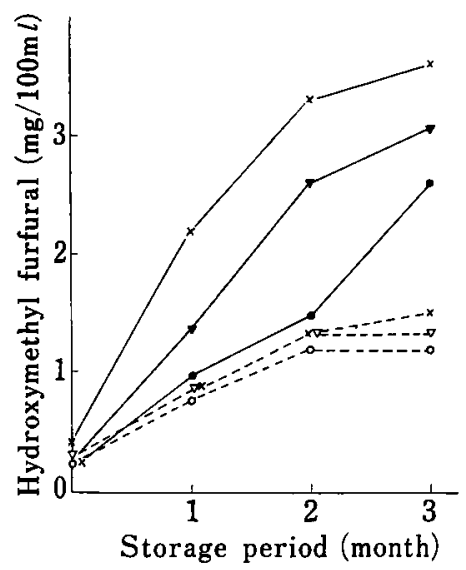

Fig. 7 Change in hydroxymethyl furfural content of Satsuma mandarin juice in standpacks (Al, KON and $\mathrm{ON}$ ) during storage

$30^{\circ} \mathrm{C}$ : Standpack (Al) - - -, Standpack (KON) $-\nabla-$, Standpack (ON) $-\times-$

$20^{\circ} \mathrm{C}$ : Standpack (Al) --O--, Standpack (KON) $--\nabla--$, Standpack (ON) - - x--

(Al) であった。このスタンドパック (Al) 果汁の HMF 增加率は貯蔵 2 力月後から際立っていた。

(4) 色調の変化

前項同様，スタンドパック 3 種類 $(\mathrm{Al}, \mathrm{KON}$ おび

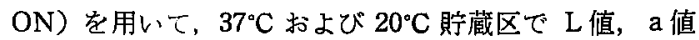
およびb值を測定した。その結果を Fig. 8 および Fig.9 に表した。

$37^{\circ} \mathrm{C}$ 眝蔵区におけるL值の減少は著しい。すなわち， スタンドパック (KON) および (ON) ともほぼ直線的 に減少しており, その減少割合は 2 力月以降で際立って いた。特にスタンドパック（ON）のL值は, 貯蔵 2 カ 月弱で 46 から 36 まで低下していた。これに対して, $20^{\circ} \mathrm{C}$ 貯蔵区の L 值はスタンドパック（ON）の低下が若 干大きいものの、3 容器間の大差は認められなかった。

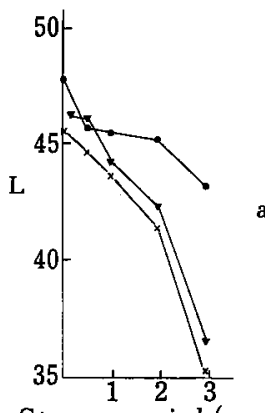

Storage period (month)

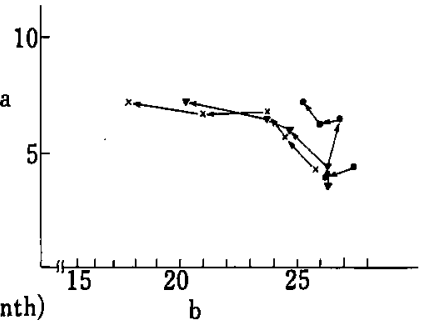

Fig. 8 Color change of Satsuma mandarin juice in standpacks ( $\mathrm{Al}, \mathrm{KON}$ and $\mathrm{ON}$ ) during storage at $37^{\circ} \mathrm{C}$

Standpack (Al) - - - Standpack (KON) $-\mathbf{-}$, Stadpack (ON) $-\times-$.

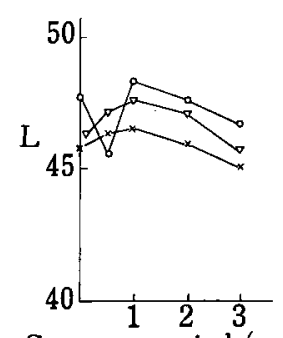

Storage period (month)

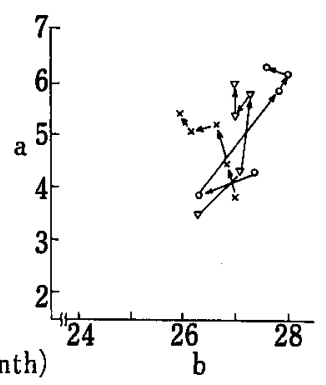

Fig. 9 Color change of Satsuma mandarin juice in standpacks ( $\mathrm{Al}, \mathrm{KON}$ and $\mathrm{ON}$ ) during storage at $20^{\circ} \mathrm{C}$

Standpack (Al) -O-, Standpack (KON) $-\nabla-$, Standpack $(\mathrm{ON})-\times-$. 


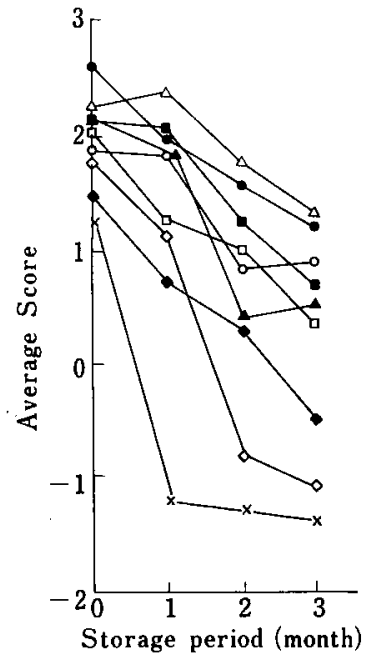

Fig. 10 Change of sensory score of Satsuma mandarin juice in various containers during storage at $37^{\circ} \mathrm{C}$

Metal can $-0-$, HF cup $-\Delta-$, PET bottle $-\square-$, Pillard pack $-\diamond-$, Standpack (Al) $-\triangle-$, Standpack (KON) $-\diamond-$, Standpack (ON) $-x-$, Glass bottle $-\bullet$, L alumi $-\square-$

$\mathrm{a}$ 值 (赤色度) および $\mathrm{b}$ 值 (黄色度) の变化では, 褐变 の進行とともに a 值より b 值の減少が顕著であった。 このb值の減少も大きい方から,スタンドパック(ON), スタンドパック (KON), スタンドパック（Al）の順で あった。

\section{(5) 官能評価}

供試容器 9 種類に充媜した 果汁をパネル15 名で貯藏 開始， 1 力月， 2 力月打よび 3 力月の計 4 回官能検查を 実施した。 $37^{\circ} \mathrm{C}$ 貯蔵区の結果を平均評点として Fig. 10 に要約した。

すでに貯蔵開始時の官能評価にバラシキが見られた。 貯蔵に従い，各容器の果汁ともにその評価は減少する。 取分けスタンドパック（ON）は貯藏 1 カ月で, またス タンドパック（KON）は眝蔵 2 カ月で非常に悪い評価 を与え, 試飲し難かった。3カ月の貯蔵で比較的評点が 高いものは, HF カップ, ガラスびん, 金属出およびL フルミ容器であった。

2. 小出し容器別（ヘッドスペースの有無）による温 州ミカン果汁の品質变化

容器を開封後小出しで使用する場合を想定し、一ッド スペースが生ずるガラスびんと内面紙ポリエチンンの可
塑性アルミニウムホイル袋から成るエフレスフロー容器 （Bag in Box）を用いて，小出し使用中に打ける果汁の 品質变化を $5^{\circ} \mathrm{C}, 20^{\circ} \mathrm{C}$ および $37^{\circ} \mathrm{C}$ で調查した。

(1) アスコルビン酸の変化

小出し使用中におけるガラスびん（1.8l 容）および

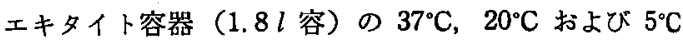

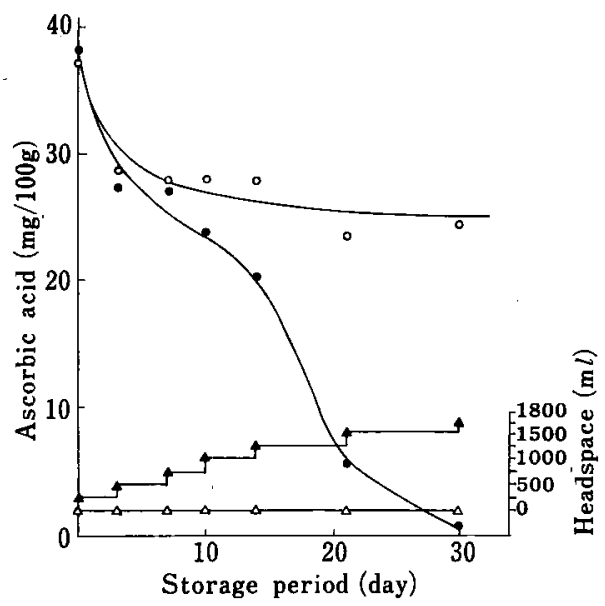

Fig. 11 Change in ascorbic acid content of Satsuma mandarin juice during storage at $37^{\circ} \mathrm{C}$

Ekitight $\begin{gathered}-\mathrm{O}- \\ -\Delta-\end{gathered}$, Glass bottle $=$

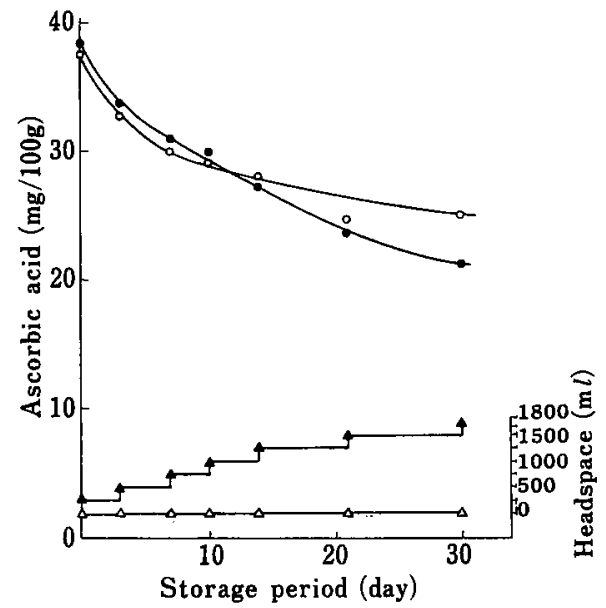

Fig. 12 Change in ascorbic acid content of Satsuma mandarin juice during storage at $20^{\circ} \mathrm{C}$

Ekitight $\begin{aligned} & -\mathrm{O}- \\ & -\mathrm{\Delta}\end{aligned}$ 


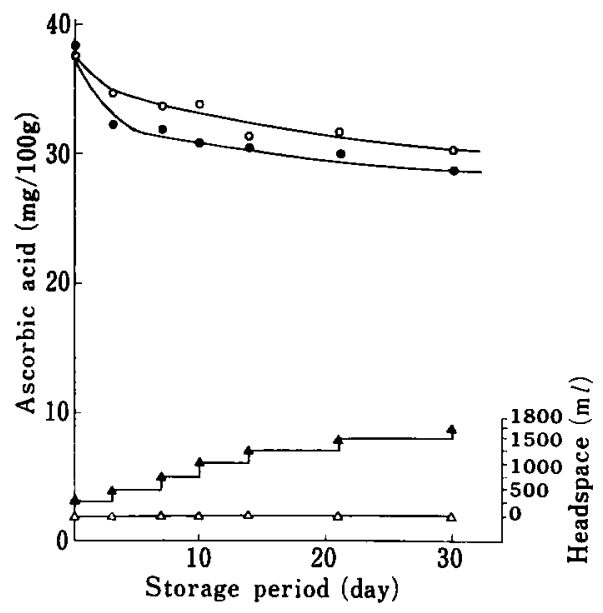

Fig. 13 Change in ascorbic acid content of Stasuma mandarin juice during storage at $5^{\circ} \mathrm{C}$

Ekitight $-\mathrm{O}-$, Glass bottle -

貯藏区のדスコルビン酸変化を，へッドスペース容量の 変化と併せて Fig. 11, Fig. 12 および Fig. 13 に記載 した。

$37^{\circ} \mathrm{C}, 20^{\circ} \mathrm{C}$ および $5^{\circ} \mathrm{C}$ のエキタイト容器において開 封実験開始時に存在したアスコルビン酸 $37 \mathrm{mg} / 100 \mathrm{~g}$ は 眝蔵初期に著しい減少を示すが，3日目以降のてスコル ビン酸减少率は低下する対数的な减少曲線を与えた。他 方，小出しのたびにへッドスペース容量が增加するガラ スびん中のアスコルピン酸は調查した $37^{\circ} \mathrm{C}, 20^{\circ} \mathrm{C}$ お

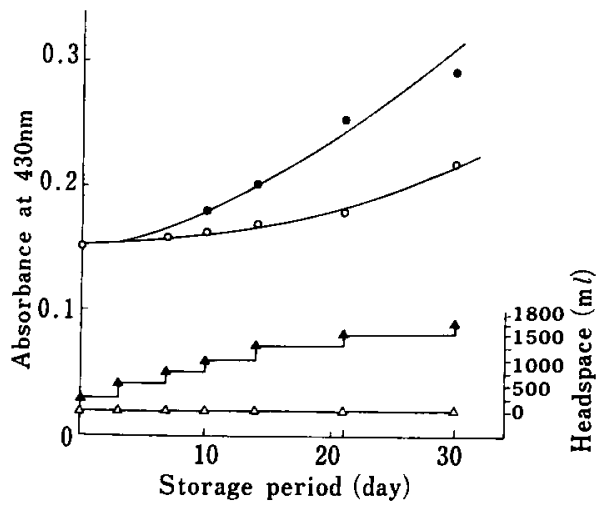

Fig. 14 Browning (OD $430 \mathrm{~nm}$ ) change of Satsuma mandarin juice during storage at $37^{\circ} \mathrm{C}$

Ekitight $-\mathrm{O}-$, Glass bottle $-\mathrm{-}-$ -
び $5^{\circ} \mathrm{C}$ の全貯蔵区でほほ直線的に减少しており，その傾 きは貯蔵温度が高いほど大である。特に， $37^{\circ} \mathrm{C}$ 区ガラ スびんのアスコルビン酸は 14 日〜21日目で $6.2 \mathrm{mg} /$ $100 \mathrm{~g}$ をで減少していた。この場合のへッドスペース容 量は $1250 \mathrm{ml}$ (残存果汁量 $750 \mathrm{ml}$ ) であった。さらに, $37^{\circ} \mathrm{C} ， 30$ 日後のアスコルビン酸はほほ完全に消失して いた。これに対して，エキタイト容器では， $37^{\circ} \mathrm{C}, 30$ 日 後でも $24.7 \mathrm{mg} / 100 \mathrm{~g}$ と当初の $66 \%$ あのアスコルピン 酸が残存していた。

(2) 褐变度の変化

小出し使用容器 2 種類の, $37^{\circ} \mathrm{C}, 20^{\circ} \mathrm{C}$ および $5^{\circ} \mathrm{C}$ にお ける褐变度变化をへッドスペース容量の变動と併せて

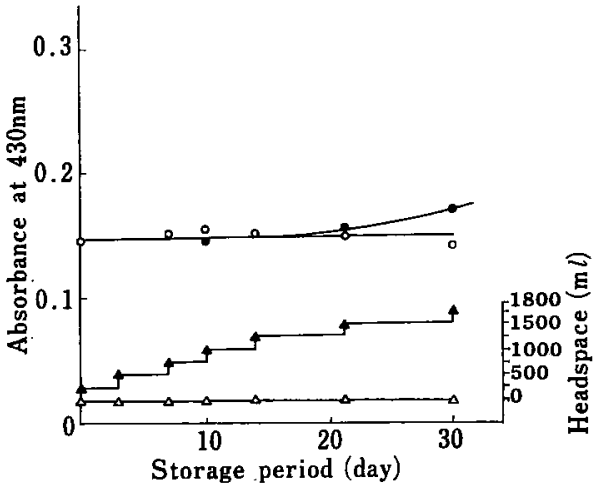

Fig. 15 Browning (OD $430 \mathrm{~nm}$ ) change of Satsuma mandarin juice during storage at $20^{\circ} \mathrm{C}$

Ekitight $\begin{gathered}-\mathrm{O}- \\ -\Delta-\end{gathered}$, Glass bottle - -

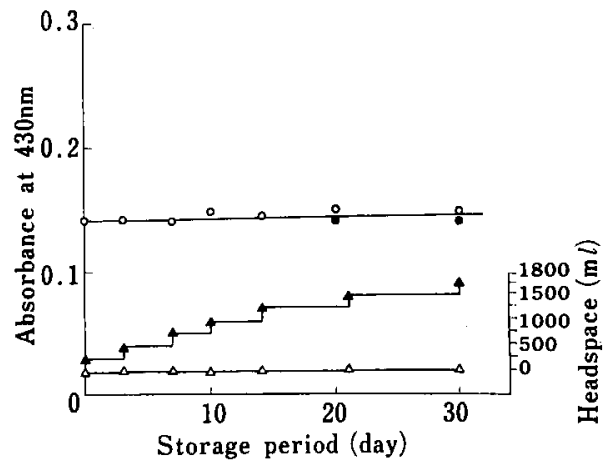

Fig. 16 Browning (OD $430 \mathrm{~nm}$ ) change of Satsuma mandarin juice during storage at $5^{\circ} \mathrm{C}$

Ekitight $-0 \ldots$, Glass bottle - 
Fig. 14, Fig. 15 および Fig. 16 に示した。 前項のアスコルビン酸の威少にともない褐变度は増加 した。その増加速度は $37^{\circ} \mathrm{C}$ 区で著しく，さらにへッドス ペース量が増大するガラスびんで顕著であった。20ㄷ における両容器の褐变度の差は 21 日目以降からみられ るが，その差は僅少であった。他方，5C 区ではへッド スペース量が増大するガラスびんとへッドスペースなし のエキタイト容器果汁の褐变度は眝蔵開始時とほとんど 変化なく一定であった。

\section{考察}

果実飲料の包装容器は，主にガラスびえおよび金属午 が使用されてきた。しかしながら，近年ではプラスチッ ク容器ならびに紙容器の市場への参入が目立っており, その用途は増加の一途にある。本傾向は空缶，空びんな どの環境污染問題ならびに食品衛生法の改正 (1982 年 2 月）と相まってさらに強まるものと予想される。今日ま でのプラスチック容器とカンキッ系果汁の品質との関連 については, バレンシフオレンジ果汁のフスコルビン酸 を対象とした報告が多い2 ${ }^{2) 55}$ 。温州ミカン果汁に関して は，島本ら の) の報告が見られるのみで，ガラスびんおよ び金属竹を含めて総合的に比較険討した研究は極めて少 ない。

そこで，著者らは今後ますます市場に流通されてくる と考えられるプラスチック容器の果実飲料に対する特性 およびその特性に見合った用途を明らかにするため，濃 縮還元温州ミカン果汁 $100 \%$ の製品を用いて，眝藏中に おける品質変化を調查した。

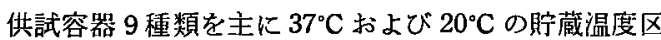
に保存し，品質劣化指標因子として前報”同棑にアスコ ルビン酸, 褐変度, HMF および色調について試験する とともに官能検查を実施した。

供試容器に充填した果汁の品質に最も大きな影響を与 えたすのは，酸素透過度と貯蔵温度であった。すなわ ち，酸素透過度が大きい容器ほど，また唄蔵温度が高い ほど，果汁の品質劣化が大であった。酸素透過が見られ る容器, スタンドパック(ON), スタンドパック(KON), ピラードパックおよび PET ボトル果汁については, フ スコルビン酸の減少 (Fig.1 および Fig.2) 褐変度の増 加 (Fig. 4 および Fig. 5) ならびに官能評価 (Fig. 10) から明らかなように，酸素透過が全くない容器と比較し てその品質は著しく劣っていた。取分け，常温流通の夏 場を想定した $37^{\circ} \mathrm{C}$ 貯蔵区の品質劣化は甚しかった。酸 素透過度の最も大きいスタンドパック（ON）では,ヘッ
ドスペースは皆無なるのの褐変度および HMF の増加は 際立っており，アスコルビン酸は貯蔵 1 カ月以内で完全 に消失していた。しかしながら，このスタンドパッタ (ON) でも $5{ }^{\circ} \mathrm{C}$ 貯蔵区, 3 カ月でフスコルビン酸の $60 \%$ 以上が残存しており (Fig. 3), 褐变度むほとえど变化し なかった（Fig. 6)。このことは，本容器が低温流通（千 ルト゚）带で十分利用可能なことを示唆している。

また, 酸素を透過しない容器でも $37^{\circ} \mathrm{C}$ 貯蔵区でアスコ ルビン酸の娍少, 褐变度, HMF および L 值の增加は大 きい。特に，Lアルミ容器は貯蔵開始時にすでに存在す るーッドスペースの影響で褐変度が大になると推測され た。

本実験では，消費者が家庭で果実飲料を消費する状況 を想定し，小出し使用時におけるへッドスペースならび に保管温度の影響安調查した。子想したように，常温保 管 $\left(20^{\circ} \mathrm{C}\right.$ 以上) ではへッドスペースを生ずるガラスびん のアスコルビン酸の減少 (Fig. 11 および Fig. 12)な らびに褐変度の増加（Fig. 14 および Fig. 15）が目立 った。特に $37^{\circ} \mathrm{C}$ 貯蔵区のフスコルビン酸は直線的に減 少していた。他方，ヘッドスペースを生成しないエキタ イト容器 (Bag in Box タイブ) のアスコルピン酸は眝 蔵初期に減少率が大きいものの 3 日目以降でほぼ一定と なり，前記へッドスペースを生じる容器よりはるかに果 汁の品質保持に寄与することを確認した。貯蔵初期にフ スコルピン酸の減少率が大きいことは，金属午でも報告 されているようにて8), 溶存遊離酸素によるアスコルビン 酸の分解と考えられた。したがって，家庭では果実飲料 を䀧入後、直ちに低温下に保管すると同時に早期に消費 することが肝要である。

アスコルビン酸は品質劣化因子として最も多く使用さ れる。ハムリンおよびバレンシフオレンジのストレート 果汁を用い，ガラスびんを対照とした冷蔵下（約 $1^{\circ} \mathrm{C}$ ) における試験では2， アスコルビン酸の残存率は貯蔵 1 カ月後でガラスびんが 95\% 以上，ポリエチレンが 90\%, 紙容器が $50 \%$ およびポリスチレンが $40 \%$ と報告されて いる。果汁品質保持の点では，これらの容器に比較して 本試験で供試したプラスチック容器の方が良好な結果を 与えた。また，泠蔵庫 $\left(3^{\circ} \mathrm{C}\right)$ 中で PVC (塩化ビニリデ ン）容器に保管し，定期的に 攪拌した果汁は，静置保 管果汁よりアスコルビン酸の分解が大きいと報告されて いるず。これは光および空気の影響とともに ${ }^{9)}$ ，本実験に おけるへッドスペースの影響ならびに酸素透過の影響と 一致する。

官能評価の結果には色調が大きく関与していた。すな 
わち，貯蔵とともに褐変反応が進行し褐変度は増加し た。この褐变反応は化学反応であるから温度の影響を著 しく受ける。促来，常温以上で $10^{\circ} \mathrm{C}$ の温度差によって， 褐変速度は 3 5 倍程度の差があると述べられている ${ }^{10) 。}$ 本実験においては，褐変度の進行が著しいスタンドパッ ク (ON) の $20^{\circ} \mathrm{C}$ から $37^{\circ} \mathrm{C}$ の褐変度の差は約 2 倍程度 であった。この褐変は低温下に冷蔵すれば事実上問題と ならなかった。

また，官能評価において貯蔵開始時にすでに容器別で バラッキが見られることは, 容器臭や味の変化とともに 興味ある課題である。

以上から，本実験に供したプラスチック容器は総合的 に見て，(1)金属缶およびガラスびえと同レベルで常温流 通に適し，1 年以上の保蔵が可能なグループ（スタンド パック (Al)，HFカップ), (2) (1)よりやや少るが, 3〜6 カ月のロングライフが可能なグループ（Lフルミ， PET ボトル)，(3)低温流通带に適し，現行のチルド果汁同様， 低温下で 2 週間前後保藏が可能なグループ（ピラードパ ック，スタンドパック(KON および ON))，に3区分 できよう。また，容器の容量との関係では，消費者が個 人で飲む場合， 1 回で飲み干せる 180 200 $\mathrm{m} l$ が適当と 考えられる。しかしながら，数人をたは個人で数回にわ たって消費する家庭内では， $1 l$ 以上の大型容器の方が 好ましいと判断されるが，乙の場合，栄盖，品質の面か ら見て, エキタイト容器のようにへッドスペースの生じ ない容器で保藏することが望をしい。

要約

各種容器が貯藏中の温州ミカン果汁の品質に及ほす影 響について試験した。12 $\mathrm{Brix}$ の温州ミカン果汁（浱縮 還元果汁)をガラスびん，金属缶（TFS 午）およびプラ スチック容器に熱間充嚗, 密封し, 水冷後, $37^{\circ} \mathrm{C}, 20^{\circ} \mathrm{C}$ あるいは $5{ }^{\circ} \mathrm{C} て ゙ 3$ 力月間貯蔵した。各試料のフスコルビ
ン酸，褐变度 (OD $430 \mathrm{~nm})$ ，ヒドロキシメチルフルフ ラールおよび官能検查を経時的に分析，調查した。

供試プラスチック容器中, スタンディングパウチ(ON/ $\mathrm{Al} / \mathrm{PE})$ および $\mathrm{Al}$ 入り積層紙カップ果汁の品質を良く 保持しており，ガラスびえおよび金属缶と匹敵した。他 方，酸素を透過するスタンディングパウチ（KON/PEお よび ON/PE) ならびにプラスチック部分補強 Al 入り 皘層紙カップは, アスコルビン酸の減少および褐変度の 堌加が大で，官能評価も悪かった。

小出し使用に打いて，へッドスペースを生じないエキ タイト容器 (Bag in Box)は, ヘッドスペースのあるガ ラスびんより良く品質を保持した。

以上のことから, 供試プラスチック容器の流通, 用途, 取り报いなどについて考察した。

\section{文献}

1）太田英明・吉田企世子・百留公朋・青楖英夫・岡 部光雄・薄田 亘：日食工誌，30，200 (1983).

2) Bissett, O. W. and Berry, R. E. : J. Food Sci., 40, 178 (1975).

3) Salem, F. M. A., Blzifzaf, S. Y. and Abdallah M. A.: Confructa, 20(4), 181 (1975).

4) Squires, S. R. and Hanna, J. G.: J. Agric. Food Chem., 27, 639 (1979).

5) Massaioli, D. and Haddad, P. R.: Food Technology in Australia, 33, 136 (1981).

6) 島本富明 - 高橋一郎・松本輝夫・大㴚正存：德島 県食品加工試駼場研究報告, No. 26, 18 (1978).

7) KefFord, J. F., Mckenzie, H. A. and Thompson, P. C. O.: J. Sci. Food Agric., 10, 51 (1959).

8) Nagy, S. and Smoot, J. M.: J. Agric. Food Chem., 25, 135 (1977).

9) Andrews, F. E. and Driscoll, P. J.: J. Amer. Dietet. Assoc., 71(8), 140 (1977).

10) 中林敏郎・木村 進・加藤博通：食品の変色とそ の化学, 再版 (光琳書院, 東京) p. 368 (1972). (昭和 58 年 2 月 17 日受理) 